\title{
Optimization of Geometrical Parameters of Fire Wood Fluidized Bed Burner
}

\author{
${ }^{1}$ Pivnenko Y., ${ }^{1}$ Burda Y., ${ }^{2}$ Redko I., ${ }^{1}$ Cherednik A., ${ }^{1}$ Alferov S. \\ ${ }^{1}$ Kharkiv National University of Civil Engineering and Architecture, Kharkiv, Ukraine \\ ${ }^{2}$ Ukraine State University of Railway Transport, Kharkiv, Ukraine
}

\begin{abstract}
The aim of this work is to determine the dynamics of the firewood burning-out in the fluidized bed burners and to select the optimal constructive characteristics of the burner of the fluidized bed, which allows decreasing the unburnt fuel particles to be carried out of the burner volume. The aims and problems were solved using the experimental and numerical methods. Thus, to determine the dynamics of the burning-out, the experimental device was used with a fluidized bed, which is a $200 \times 300 \mathrm{~mm}$ chamber $1000 \mathrm{~mm}$ high. The fuel mass of each combustion cycle was similar. It was $3.8 \mathrm{~kg}$. The average time of burning-out during the combustion full cycle was in the range of 300-500 s, the maximum temperature of the layer was $800^{\circ} \mathrm{C}$. The studies performed showed that the major problem in the wood waste combustion is the insufficient time of the combustion process in the burner. This problem was proposed to be solved using the cone-shaped burner. The mathematical method was developed to determine the optimal main construction parameters ( $D$ is the top diameter; $\mathrm{d}$ is the bottom diameter and $\mathrm{H}$ is the cone height) of the burner accounting for the solid particle motion rate in the ascending flow. The devolatilization parameter of material was used as the optimization parameter. The most significant results are those cone-shaped geometrical parameters optimized in the research process. The significance of the results obtained is that the results of the above studies can be used in practice for designing the boilers with the fluidized bed burners.
\end{abstract}

Keywords: burner, fluidized bed, wood waste, burning-out rate, optimization, numerical experiment, temperature.

DOI: https:// doi.org/10.52254/1857-0070.2021.2-50.05

UDC: 697.325

Optimizarea parametrilor geometrici ai focarelor de strat fluidizat pentru combustibil lemnos

${ }^{1}$ Pivnenko Iu. A., ${ }^{1}$ Burda Iu. A., ${ }^{2}$ Rediko I. A., ${ }^{1}$ Cerednik A. D., ${ }^{1}$ Alfiorov S. A.

Universitatea Națională din Harkov de construire și urbanism

Harkov, Ucraina

${ }^{2}$ Universitatea Ucraineană de Stat de transport feroviar

Harkov, Ucraina

Rezumat. Scopul acestei lucrări este de a determina dinamica arderii combustibilului din lemn în cuptoarele cu pat fluidizat și de a selecta caracteristicile optime de proiectare ale cuptorului de fierbere, ceea ce va reduce transferul particulelor de combustibil nearse din volumul cuptorului. Obiectivele și sarcinile stabilite au fost rezolvate prin metode experimentale și numerice. Deci, pentru a determina dinamica arderii, a fost utilizată o instalație experimentală cu pat fluidizat, care este o cameră cu dimensiuni de 200x300 mm și înălţimea de 1000 mm. Masa de combustibil în fiecare ciclu de ardere a fost aceeași şi s-a ridicat la 3,8 kg, timpul mediu de ardere pentru un ciclu complet de ardere a fost de $300 \ldots 500 \mathrm{~s}$, temperatura maximă a patului a fost de $800{ }^{\circ} \mathrm{C}$. În urma cercetărilor efectuate, s-a depistat, că cea mai mare problemă a arderii deșeurilor lemnoase este timpul insuficient de ședere a combustibilului în volumul cuptorului. Se propune rezolvarea acestei probleme prin construirea unui cuptor în formă de con. Cele mai semnificative rezultate sunt parametrii geometrici ai cuptoarelor în formă de con, optimizați ca urmare a cercetării. Ca rezultat al studiilor, raporturile principalilor parametri de proiectare a cuptoarelor pentru arderea deșeurilor lemnoase au fost confirmate, raportul D / d ar trebui să fie 2,8, înălțimea totală a conului să fie de cel puțin 2,2 din înălțimea patului fluidizat într-o stare staționară. Semnificația rezultatelor obținute constă în aplicabilitatea acestor studii în practică la proiectarea cazanelor cu cuptoare cu pat fluidizat.

Cuvinte-cheie: cuptor, pat fluidizat, combustibil lemnos, rata de ardere, optimizare, experiment numeric, temperatură.

(C) Yurii Pivnenko, Yurii Burda,

Igor Redko, Artem Cherednik,

Sergei Alferov, 2021 


\section{Оптимизация геометрических параметров топок кипящего слоя для древесного топлива ${ }^{1}$ Пивненко Ю. А., ${ }^{1}$ Бурда Ю. А., ${ }^{2}$ Редько И. А., ${ }^{1}$ Чередник А. Д., ${ }^{1}$ Алферов С. А. Харьковский национальный университет строительства и архитектуры Харьков, Украина \\ ²Украинский государственный университет железнодорожного транспорта Харьков, Украина}

Аннотация. Целью данной работы является определение динамики выгорания древесного топлива в топках кипящего слоя и подбор оптимальных конструктивных характеристик топки кипящего, позволяющие снизить унос несгоревших частиц топлива из объема топки. Поставленные цели и задачи решались экспериментальными и численными методами. Так, для определения динамики выгорания использовалась экспериментальная установка кипящего слоя, которая представляет собой камеру размерами 200х300 мм, высотой 1000 мм. Масса топлива в каждом цикле сжигания была одинаковой и составляла 3.8 кг, среднее время выгорания при полном цикле сжигания составило $300 \ldots 500$ с, максимальная температура слоя составляла $800^{\circ} \mathrm{C}$. В результате проведенных исследований выявлено, что самой большой проблемой сжигания древесных отходов является недостаточное время пребывания топлива в объеме топки. Данную проблему предложено решить путем конструктивного исполнения топки в конусообразной форме. Была разработана математическая модель для определения оптимальных основных конструктивных параметров топки (верхний диаметр D, диаметр основания d и высота конуса H) которая учитывает скорость движения твердой частицы в восходящем потоке. Предложена расчетная позволяющая определить данные параметры. Оптимизированные параметры получены в результате статистической обработки данных методом планирования вычислительного эксперимента. В качестве параметра оптимизации выбран параметр показателя уноса материала. Наиболее существенными результатами являются оптимизированные в результате исследований геометрические параметры топок конусообразной формы. В результате проведенных исследований обоснованы соотношения основных конструктивных параметров топок для сжигания древесных отходов, соотношение D / d должно составлять 2.8 , общая высота конуса должна составлять не менее 2.2 от высоты кипящего слоя в стационарном состоянии. Значимость полученных результатов состоит в том, что результаты данных исследований могут быть применены на практике при конструировании котлов с топками кипящего слоя.

Ключевые слова: топка, кипящий слой, древесное топливо, скорость выгорания, оптимизация, численный эксперимент, температура.

\section{INTRODUCTION}

The wood waste has a number of distinctions from other kinds of solid fuel, in particular, from fossil fuels. Compared to coal, the wood is a more complicated fuel from the viewpoint of the combustion technology. The firewood waste (sawdust, woodchips, cutting waste, etc.) are characterized with high volatibility and a relatively small mass. In addition, the content of the volatiles in the wood waste reaches $85 \%$ [9]. The aforementioned data can negatively affect the wood combustion efficiency. Because of the insufficient height of the space above the layer, incomplete burning of volatile particles and carrying away the inflammable particles are possible. The incomplete burning problem is solved using the air additional supply into the above-layer space, where the volatile particles burn down.

To ensure the mechanical completion of the combustion the problem is being solved on the gas flow rate decrease and an increase in time of the fuel particles presence in the burner volume using the constructive optimization of the burner space.
The fuel particles, which get into the overlayer space, are carried out into the atmosphere fairly quickly. This results from the fact that fluidization rate usually exceeds that of lingering the wood waste particles. The obvious solution of this problem is supposed to be in the gas flow rate decrease in the over-layer space.

The important parameter that affects the operational modes of the boiler with a fluidized bed burner, is the fuel burning-out rate.

The combustion duration is affected by various factors such as fuel humidity, combustion temperature, ash content, air-blast consumption, etc. [10-19].

The experimental results on combustion of fuel granules of different kinds of vegetable origin wastes are described in [1]. The experimental burning time in combustion presented by the authors is considerably less, than that given in this work's data. However, it is noteworthy that in the experiments on agro-pellets combustion other kinds of modes of combustion were applied. Temperature of the boiling layer reached $900{ }^{\circ} \mathrm{C}$ and higher than that. This accelerated the combustion process.

In addition, the authors [1] burnt the fuel 
supplying it onto the heated ash layer, whereas in the above experiment the burning process started with the ignition at the environmental temperature, which allowed us to define more precisely the ignition duration for each kind of fuel separately.

The burn-out dynamics of wood sawdust and sunflower husk were studied in [20]. The fuel was supplied into $0.1 \mathrm{~g}$ fluidized bed reactor, which was preliminarily heated to $900^{\circ} \mathrm{C}$. The inert material (ash) was $1 \mathrm{~g}$. The burn-out time of the samples was 24-60 s. These data were supported by the theoretical calculations [21].

The burn-out dynamics of the fuel in the fluidized layer chambers and the increase in time of the inflammable particles period in the burner's space are studied insufficiently. The recommendations on optimization of constructive solutions on the fluidized bed burners are absent.

In the above foreign sources, the evaluation of the constructive solutions on the devices for the period of staying the particles in the volume of the above devices was not performed. Thus, during the combustion of the peanut shells, the effect of the conical form of the burner was not shown [22]. Work [23] is of great interest. The approach offered in the paper uses the equation system, which connects the diameters of the particles in a layer as a function of the layer height, the angle of the wall slope, the rate of the ascending stream and the diameter of the air distributer. However, the index of the material carry-off was not studied. The authors of [24], obtained the empiric equations, which allowed them to determine the rate of fluidization and the values of the pressure drop in the layer, with the rate of fluidization being dependent on the geometrical shape of the burner, therefore, this problem is yet to be researched. In [25], the authors describe the conic shape of the air distributor and its effect on the hydraulic modes of the fluidized bed. The approach of [26] is as well directed on the study of the hydraulic modes of the conic apparatuses with a fluidized bed without the account for the effect of their geometrical parameters. A principal distinction of this work consists in the approach to the constructive optimization of the burner for the establishing of the hydraulic modes of operation of the boilers having the fluidized bed burners and a minimized particle carry off.

Purpose of work. The work is devoted to the experimental study of the burning-out processes of the wood fuel, using the laboratory facility of the fluidized bed. The methods for the numerical experiment are to be used for determination the optimal constructive characteristics of the fluidized bed burner, which make it possible to reduce the carry-away process of the unburnt fuel particles from the burner volume.

\section{METHODS, RESULTS AND DISCUSSION}

The experiments used to determine the fuel burn-out rates were performed on the laboratory device (Fig. 1), which consists of a 200x300 mm chamber, $1000 \mathrm{~mm}$ high. It is equipped with an automatic fuel supply system. The air is pumped into a VVD-5 ventilator. There is an air distributer grid. The surface emerged in the layer is an $18 \mathrm{~mm}$ pipe. To improve the precision of the studies a thermocouple was introduced in its external wall. The water temperature was measured at the inlet and output.

The following temperature measurements were performed using this experimental device:

- temperature of the fluidized bed;

- temperature of the above layer space;

- temperature of smoke gases;

- temperature of water at the inlet of the emmersed pipe;

- temperature of water at the output of the emmersed pipe;

- temperature at the pipe surface;

- temperature of the air at the device inlet.

The TCA and TCR thermocouples were applied.

To register the temperature and data transfer in the on-line mode to the computer, the eightchannel temperature a RegMic IL8 recorder was used. The transfer of the thermocouple readings occurred each second through an RS-242 interface.

The fuel combustion was performed using the method for the cyclic fuel supply into the device. Each cycle was three-staged: ignition, fuel burning with a temperature increase in the layer and burning the fuel down at the moment of the fuel supply pause. The fuel mass at each combustion cycle was similar, $3.8 \mathrm{~kg}$. The burning down rate of the wood sawdust is the highest among the materials proposed. Probably, the reason for this is the low density of the sawdust. On the whole, the time of combustion for all kinds of fuel ranged from 300 to $500 \mathrm{~s}$. The longest time for starting a fire was in the case of burning the wood granules. This can be explained by that the density of this material is much higher than that of the sawdust or woodchip. 
Below are the results of the experimental studies of the fire-wood (granules, sawdust, woodchips) burn-out in the fluidized bed (Fig. 2).
Temperature rise is shown depending on time of burning. The efficient decrease in the flow rate is possible to be realized using the proposed

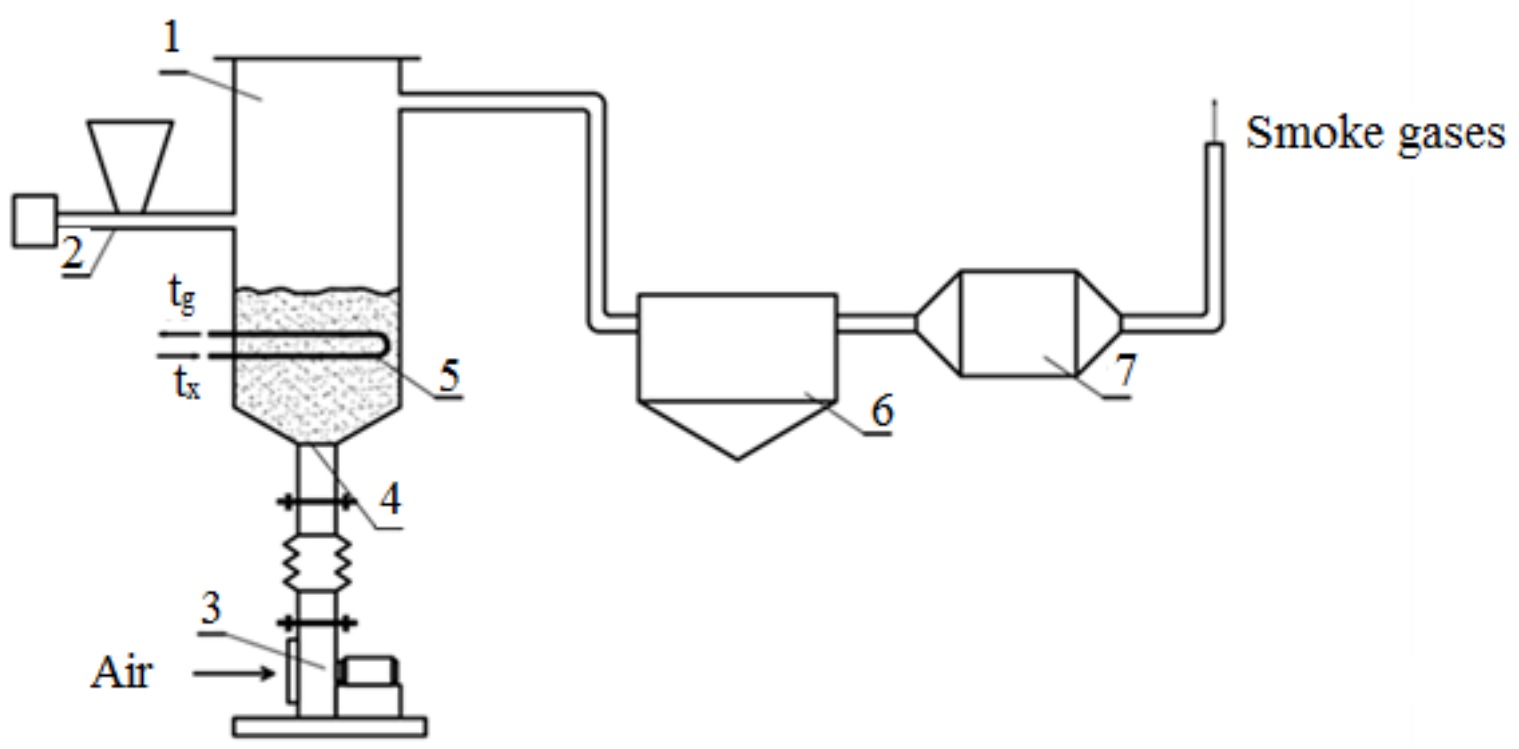

1 - frame; 2 - screw feeder fuel supply system; 3 - ventilator; 4 - air distribution grid; 5 - surface immersed into fluidized bed; 6 - dust precipitation chamber; 7 - cloth filter, $t x$ - cold water supply into the immersed pipe, $t_{x}$ heated water issue from immersed pipe.

Fig. 1. Experimental device to study wood waste combustion in fluidized bed.

construction, namely, by the use of the conic carry-off will be the height of the fluidized bed burner variant (Fig. 3). that affect the material

$H_{0}$, the height of the above-layer space

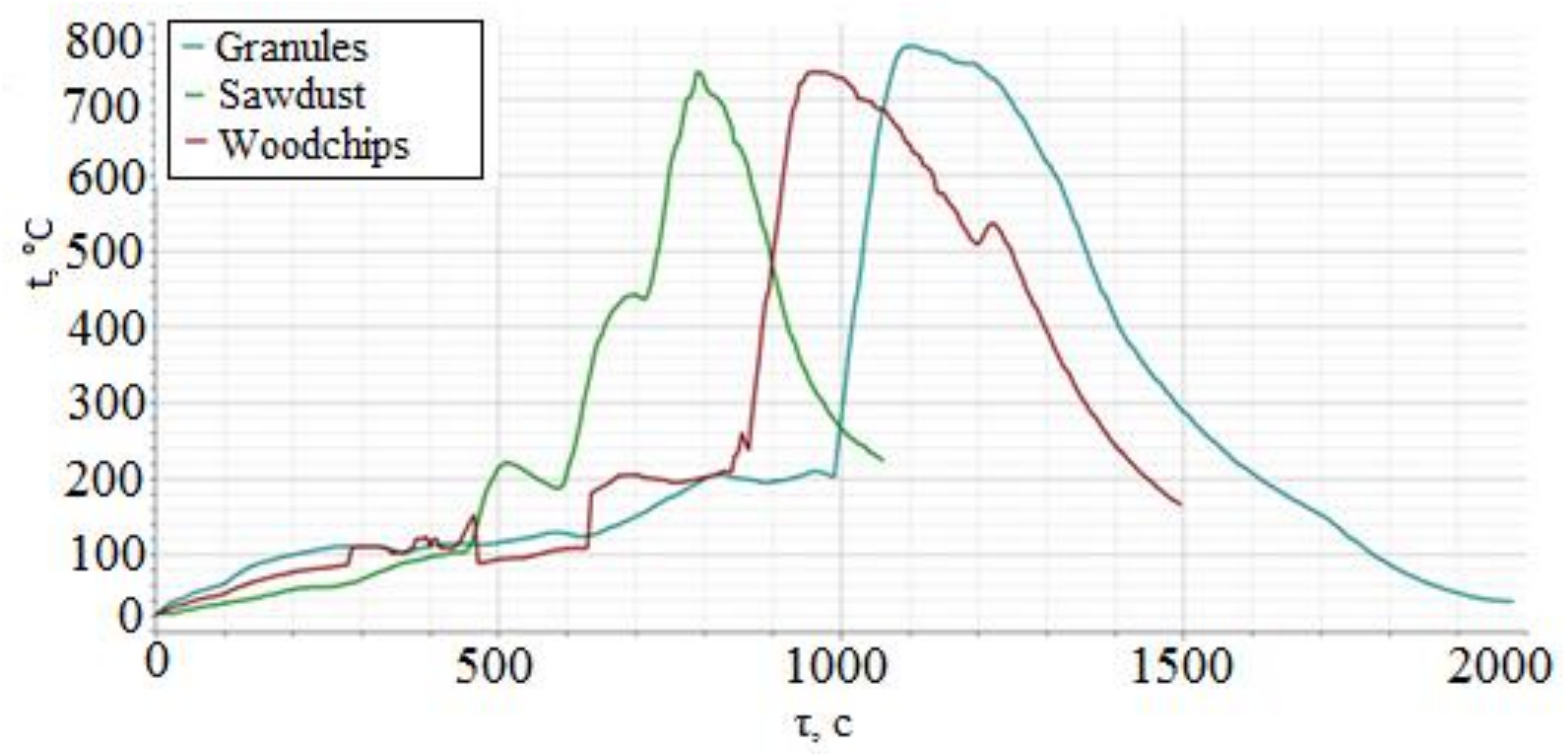

Fig. 2. Burning duration of different wood fuel types.

$H_{s}$, diameter of the lower part of the cone $d_{0}$, and diameter of the top part of the cone dt. Accepting the fixed height of the fluidized bed, we shall get three values, which determine the optimal burner design: $H_{s}, d_{0}, d_{t}$ The ascending fuel flows were described in [27-34].
To solve the above problems the model is offered based on the works of the famous scientists such as Leva M., Davidson J.F., Gel'perin N. I, Gorbis Z. R, Pomerantsev V. V., Todes O. M [35-40]. The amount of material carried off from the burner can be assessed using the following formula: (1): 


$$
\frac{G_{c}}{G}=A \frac{w^{4}\left(C^{\prime \prime}\right)^{0,5}}{\left(d_{c}^{\prime \prime}\right)^{3,53} \varphi} \frac{H_{0}^{K}}{H_{s}^{n}} m_{v}^{4}
$$

where $G$ is the mass rate of the gas, $\mathrm{kg} / \mathrm{s}$; $G_{c}$ is the carry-off mass rate, $\mathrm{kg} / \mathrm{s}$;

$w$ is the fluidization, $\mathrm{m} / \mathrm{s}$;

$d_{c}^{\prime \prime}$ is the weight-average diameter of fine particles of the layer, $\mu \mathrm{m}$;

$H_{0}$ is the layer height, $\mathrm{mm}$;

$H_{s}$ is the height of the over-layer space, mm;

$C^{\prime \prime}$ is the concentration of the fine material in the over layer space \%;

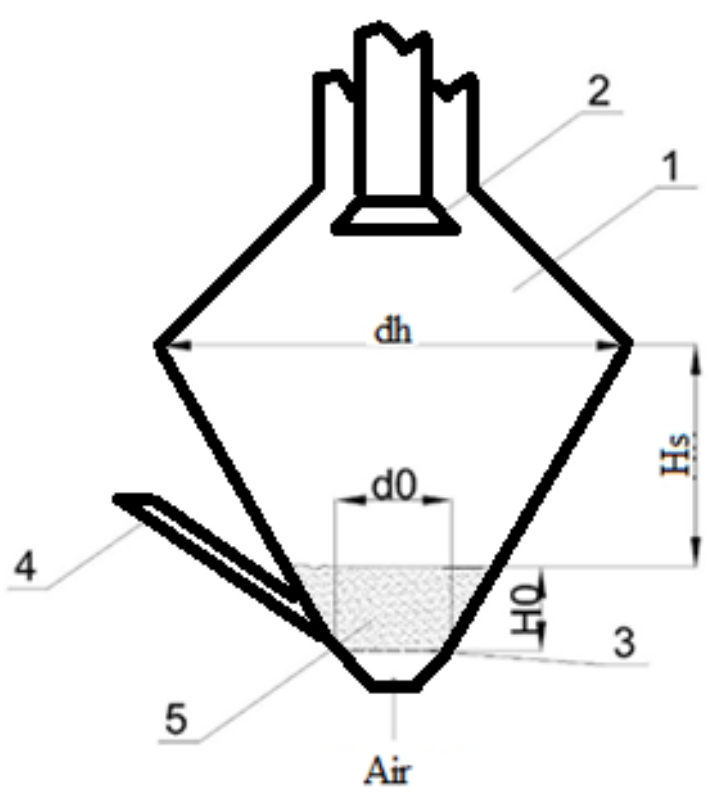

1 - burner frame; 2 - system for secondary air supply; 3 - air distribution grid; 4 - fuel supply system; 5 - fluidized bed of wood fuel.

Fig. 3. Design of fluidized bed burner for wood fuel combustion.

$K$ is the degree index, equal to 0.359 ;

$\varphi$ is the share of the clear area of the cross section of the air distributor of the lattice, \%; $A$,

$n$ are the values, which depend on the $H_{0}$ and $H_{s}$ ratio. If $H_{s} \leq H_{0}$, then $A=10^{9}, n=1,01$. If $H_{s}>H_{0}$, then $A=3,35 \cdot 10^{5}, \quad n=0,273$; $m_{v}=w_{l}^{\prime} / w_{l}$ is the correction coefficient; $w_{l}$ is the lingering rate, $\mathrm{m} / \mathrm{s}$.

Index 'relates to the catalyst-air system.

The concentration of the particles in the fluidized bed can be determined any time using (2):

$$
C^{\prime \prime}=C_{0}^{\prime \prime} e^{k " \tau}
$$

where $C_{0}^{\prime \prime}$ is the initial concentration of the fine grain material layer;

$k^{\prime \prime}$ is the constant of the carry-off rate. It is calculated using the Leva formula:

$$
k^{\prime \prime}=2,48\left(\frac{w-w_{l}}{w l}\right)^{1,3} \frac{d_{l}^{0,7}}{H_{0}^{1,4}}
$$

where $d_{l}$ is the diameter of the particles of main component, $\mathrm{m}$.

The lingering rate depends on the hydraulic mode of fluidizing and is calculated as follows:

- the Stocks law operates for the laminar mode:

$$
w_{l}=g \frac{\left(\rho_{m}-\rho_{a}\right) d^{2}}{18 \mu}
$$

where $\rho_{M}$ is the material density, $\mathrm{kg} / \mathrm{m}^{3}$;

$\rho_{M}$ is the air density, $\mathrm{kg} / \mathrm{m}^{3}$;

$d$ is the average diameter of particles, $\mathrm{m} ; \mu$ is the coefficient of the air dynamic viscosity, $\mathrm{Pa} \cdot \mathrm{s}$. The lingering rate for the turbulent mode is calculated using (5):

$$
w_{l}=\sqrt{3,03 g d \frac{\rho_{m}-\rho_{a}}{\rho_{a}}}
$$

The lingering rate for the transitional mode is calculated in accordance with the Allen formula:

$$
w_{l}=0,153 \frac{\left(\rho_{m}-\rho_{a}\right)^{0,714} d^{1,142} g^{0,286}}{\rho_{a}^{0,286} \mu^{0,428}}
$$

Dynamic viscosity is calculated using the Sutherland formula:

$$
\mu=\mu_{n . c .} \cdot\left(\frac{T_{n . c .}+C}{T+C}\right) \cdot\left(\frac{T .}{T_{\text {n.c. }}}\right)^{3 / 2}
$$

where $\mu_{\text {n.c. }}$ is the air dynamic viscosity under normal conditions, $\mathrm{Pa} \cdot \mathrm{s}$;

$T_{n . c .}$ is the air temperature under normal conditions, $\mathrm{K}$;

$C$ is the Sutherland constant.

The air density is determined using (8):

$$
\rho_{a}=\rho_{\text {n.c. }} \cdot T_{\text {n.c. }} / T
$$


To define the rate of the fluidization beginning the authors offer to modify the Todes equation using the following ratios:

$$
\begin{gathered}
\frac{w_{c}}{w_{0}}=\left(\frac{d_{h}}{d_{0}}\right)^{2}, \alpha \leq 10^{\circ} \\
\frac{w_{c}}{w_{0}}=\left(\frac{d_{h}}{d_{0}}\right)^{1,44}, \alpha \geq 20^{\circ}
\end{gathered}
$$

$\frac{w_{c}}{w_{0}}-$ is the ratio of the rate of fluidization beginning in the conical device to the fluidization rate in the permanent diameter device.

Accepting the cone walls angle beyond $20^{\circ} \mathrm{C}$, we shall obtain:

$$
\operatorname{Re}=\left(\frac{d_{h}}{d_{0}}\right)^{1,44} \frac{A r}{150 \frac{1-\varepsilon}{\varepsilon^{3}}+\left(\frac{1,75}{\varepsilon^{3}} \cdot A r\right)^{0,5}}
$$

The rate of the wood fuel burning-out can be obtained from equation (12):

$$
\tau=\frac{1}{4 M c} \cdot \frac{\rho_{M} R T}{N u_{D} \cdot D \cdot p_{1 \Delta}} d^{2}
$$

$M c$ is the carbon molar mass, $\mathrm{kg} /$ mole;

$N u_{D}$ is the Nusselt mass-exchange criterion;

$p_{1 \Delta}$ is the pressure in the burner, $\mathrm{kPa}$;

$D$ is the diffusion coefficient; $R$ is the universal gas constant.

$$
\begin{gathered}
D=D_{0}\left(\frac{T}{T_{0}}\right)^{n} \\
D_{0}=0,149 \cdot 10^{-4}, n=2,0 \\
N u_{D}=2+0.03 \operatorname{Pr}_{D}^{0.33} \operatorname{Re}_{D}^{0.54}+\operatorname{Pr}_{D}^{0.36} \operatorname{Re}_{D}^{0.8}
\end{gathered}
$$

The solid particle motion rate in the ascending flow is determined using (16):

$$
\tau_{s}=\frac{w_{l}}{2 g} \ln \left(\frac{w_{d}-w_{b}}{w_{d}+w_{b}}\right)\left(\frac{w_{i}-w_{l}}{w_{i}+w_{l}}\right)
$$

where $w_{d}$ and $w_{i}$ denote the initial and finite gas flow rates, $\mathrm{m} / \mathrm{s}$.

The necessary height of the separation space is defined using (17):

$$
H_{s}=w \tau_{s}-\frac{w_{l}^{2}}{g} \ln \frac{s h \gamma\left(w_{d}^{2}-w_{l}^{2}\right)^{0,5}}{w_{l}}
$$

$\gamma$ is the dimensionless coefficient.

$$
\gamma=\frac{\tau_{s} \gamma}{w_{l}}+0,5 \ln \frac{w_{d}+w_{l}}{w_{d}-w_{l}}
$$

It is obvious that the height of the separation space depends on the correlation between the cone upper and lower diameters. Note that there are certain limitations to it. With the account for the fairly high significance of the devolatilization for the wood fuel, it must be considered that the overlayer space should be sufficient enough for the gas entire combustion. In addition, the larger the cone upper diameter, the more complicated the fluidization mode. The situation can happen, when the fluidization does not occur at all near the burner walls. Below, the calculation results are presented showing the effect of the correlation between the upper and lower cone diameters on the separation space height. In all calculations, the accepted particle diameter was $3 \mathrm{~mm}$, the layer temperature was $900{ }^{\circ} \mathrm{C}$ and the share of the lattice open area was $15 \%$.

The graph (Fig. 4) shows that at the cone form, which is close to that of a cylinder, the height of the separation space, which is necessary for the fuel total burning out, can reach beyond $10 \mathrm{~m}$. The effect of the cone diameters on the ablative parameter at different heights of the over-layer space is shown in Fig 5.

The dependence of the ablative parameter on the height of the over-layer space at different values of correlation between the cone diameters is shown in Fig. 6.

Thus, considering the above calculation results, to ensure the maximum efficiency of the wood waste combustion in the cone-shaped burner with the fluidized bed, the following geometrical parameters must be accepted: the ratio of $D / d(d h / d 0)$ is 2.8 ; the general cone height is up to 2.2 of the fluidized bed height in the stationary state.

The time of burning-out of the fuel particles in the given calculations was $\sim 20 \mathrm{~s}$. Note that for the large-fraction fuel the burning-out time is longer and the devolatilization of fine inclusions is more intense, however, having a large weight compared to fine-fraction fuel, the presence duration of large particles in the burner will be longer-lasting

The statistical data processing was performed using the method for the mathematic planning. 
Devolatilization was chosen to be the optimization parameter.

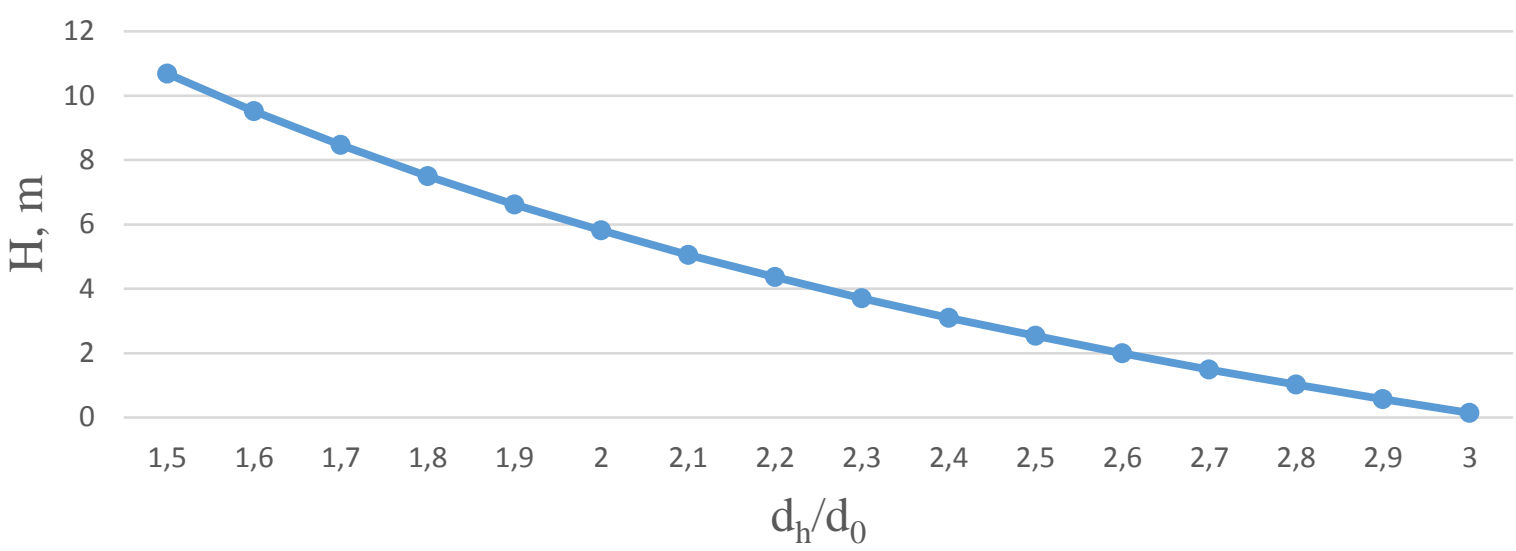

Fig. 4. The effect of the correlation between the top diameter and bottom diameter of cone on height of separation space.

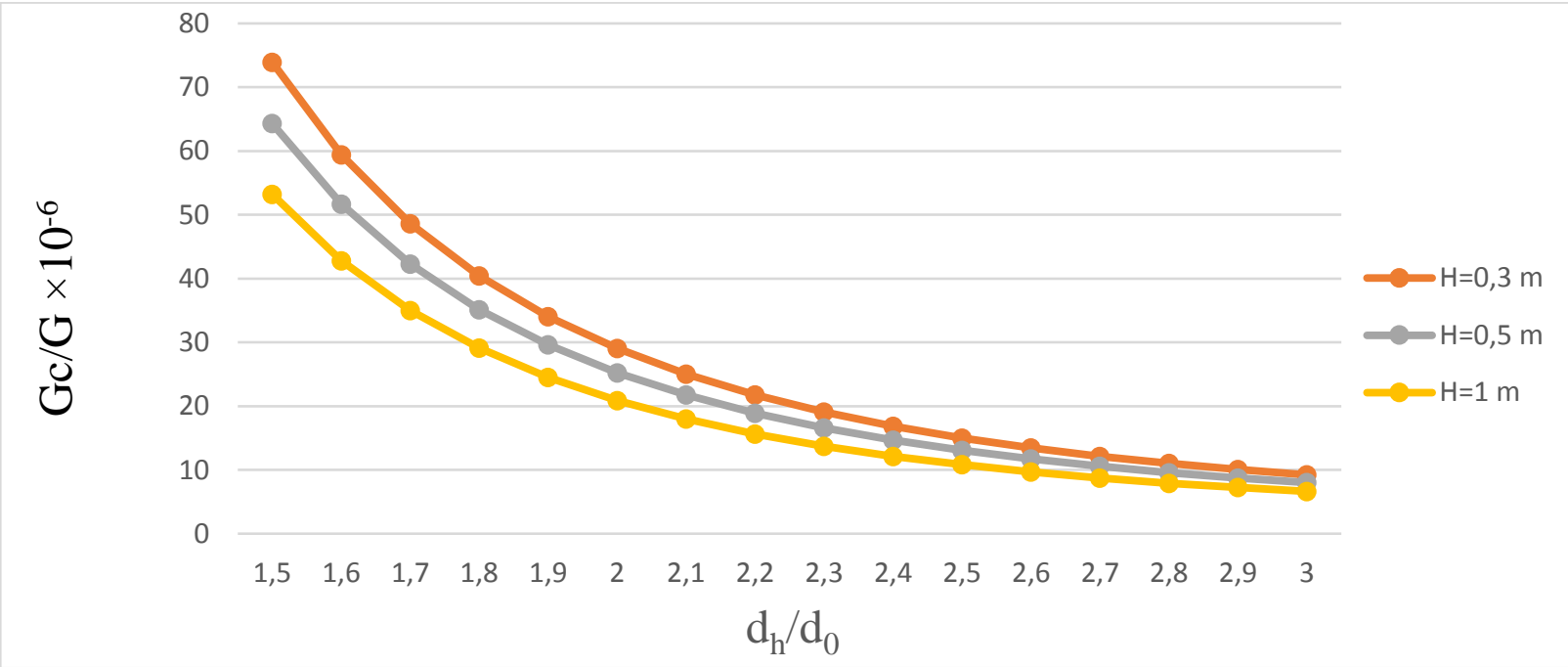

Fig. 5. Effect of cone diameters on devolatilization parameters at different heights of the over-layer space.

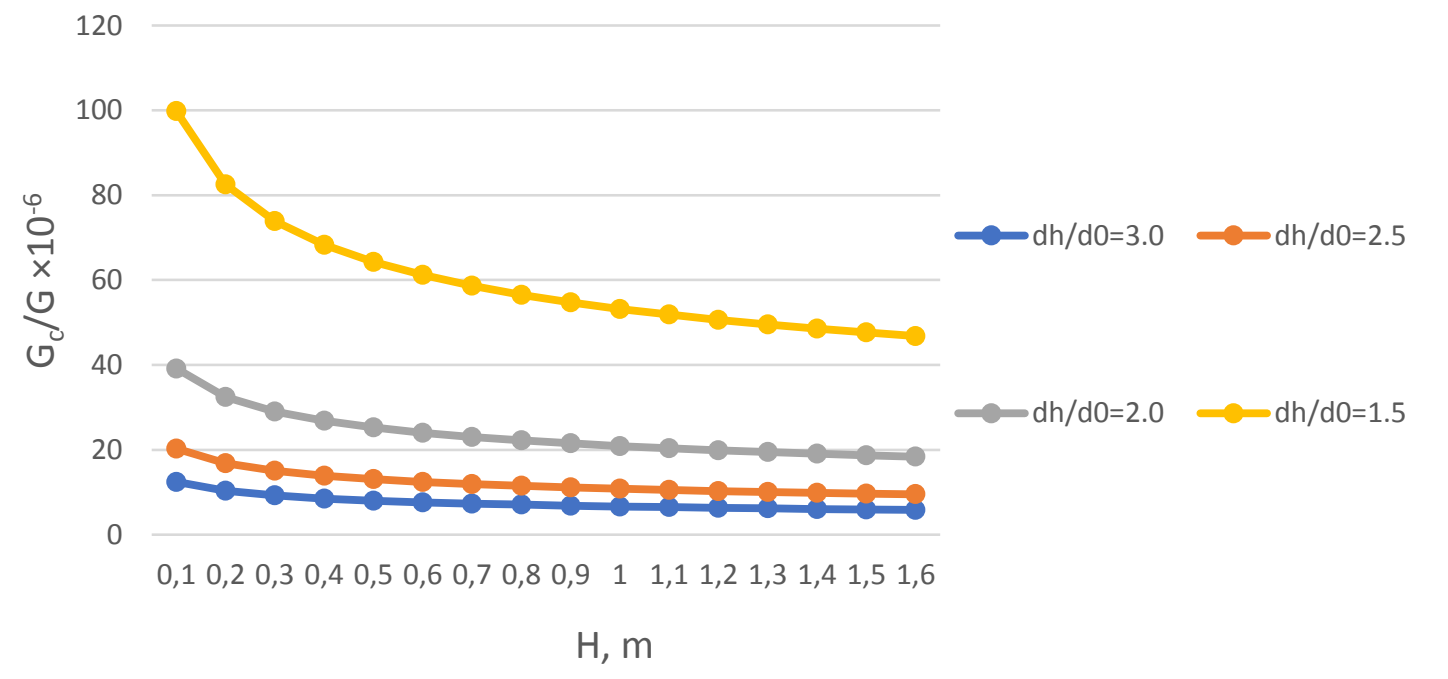

Fig. 6. Dependence of devolatilization parameter on the height of over-layer space at different correlation values of cone diameters. 
Table 1.

Matrix-plan of the experiment.

\begin{tabular}{|c|c|c|c|c|}
\hline \multirow{2}{*}{ Name of factor } & \multirow{2}{*}{$\begin{array}{l}\text { Code } \\
\text { value }\end{array}$} & \multicolumn{3}{|c|}{ Factor values } \\
\hline & & -1 & 0 & +1 \\
\hline Correlation between top and bottom diameters & $x_{1}$ & 2,0 & 2,5 & 3,0 \\
\hline Dependence of over-layer space on layer height & $x_{2}$ & 1,0 & 2,0 & 3,0 \\
\hline
\end{tabular}

Table 2.

Matrix-plan of the experiment.

\begin{tabular}{|c|c|c|c|}
\hline № experiment number & $x_{1}$ & $x_{2}$ & $y$ \\
\hline 1 & - & - & $y_{1}$ \\
\hline 2 & 0 & - & $y_{2}$ \\
\hline 3 & + & - & $y_{3}$ \\
\hline 4 & - & 0 & $y_{4}$ \\
\hline 5 & 0 & 0 & $y_{5}$ \\
\hline 6 & + & 0 & $y_{6}$ \\
\hline 7 & - & + & $y_{7}$ \\
\hline 8 & 0 & + & $y_{8}$ \\
\hline 9 & + & + & $y_{9}$ \\
\hline
\end{tabular}

The regression equation is obtained, which shows the dependence of the devolutilization on the burner geometrical parameters. The response surface is shown in Fig. 7.

$$
\begin{aligned}
& G_{\mathrm{c}} / G=127,4794-73,57 \cdot d_{\mathrm{h}} / d_{0}-4,6642 \\
& \cdot H_{s} / H_{0}+11,8533 \cdot\left(d_{h} / d_{0}\right)^{2}- \\
& \quad-0,195 \cdot d_{h} / d_{0} \cdot H_{s} / H_{0}+0,9183 \cdot\left(H_{s} / H_{0}\right)^{2}
\end{aligned}
$$

The ratio D/d must be 2.8 , and the general height of the cone must be up to 2.2 of the of the fluidized bed height in a steady state.

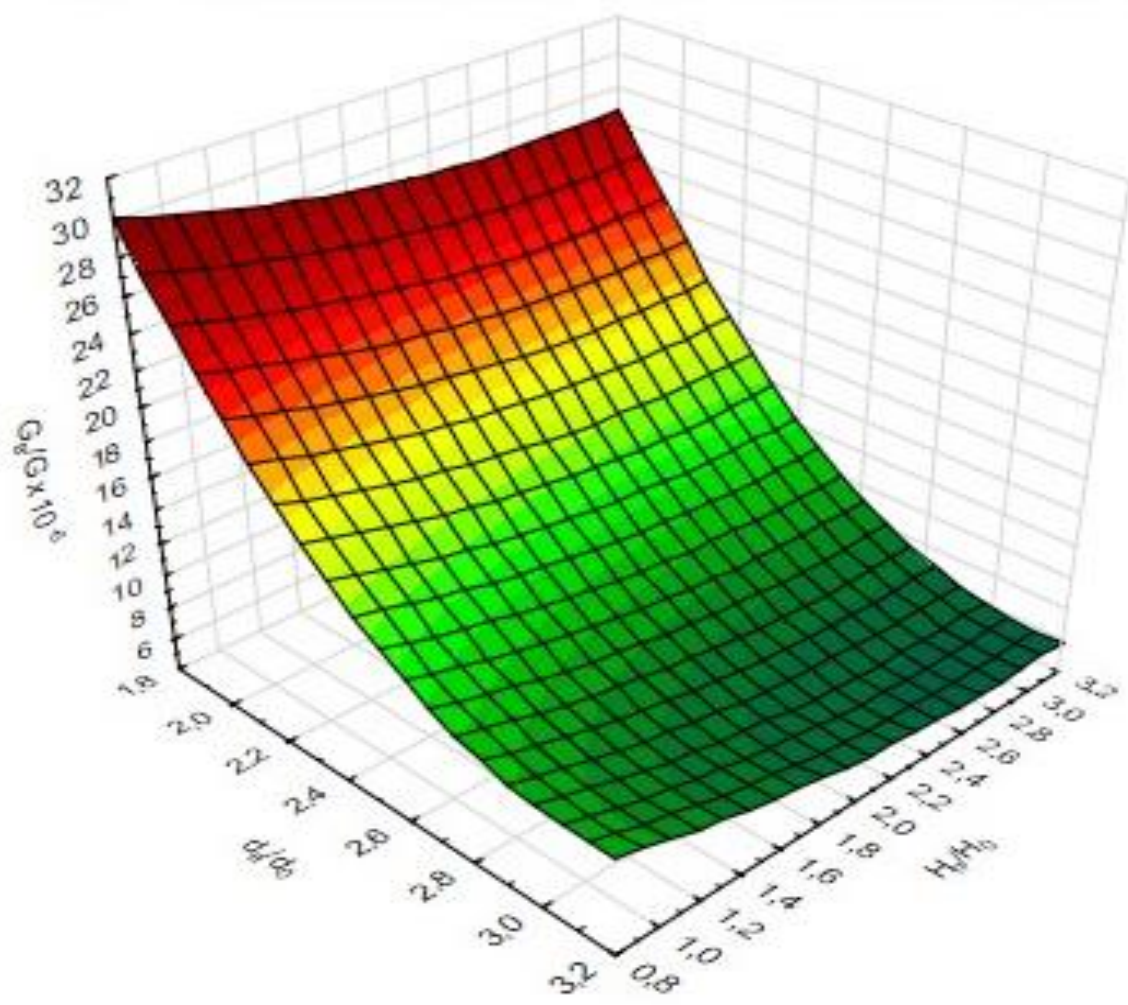

Fig. 7. Dependence of devolatilization parameter on the burner geometrical parameters.

\section{CONCLUSIONS.}

The results of the researches on optimization of the geometrical parameters of the burners with a fluidized bed of the wood fuel exhibited that the most important problem of the wood-waste combustion is the insufficient time of the fuel burning in the burner volume. This problem is proposed to be solved using the cone-shaped burner. The mathematic model was developed to determine the optimal main structural parameters of the burner ( $D$ is the top diameter; $d$ is the bottom diameter and $\mathrm{H}$ is the cone height). Applying the planning method of the calculation experiment and statistic data processing, the coneshaped burner geometrical parameters 
optimization was performed. The regression equation of the dependence of the

devolatilization value on the burner geometrical parameters was shown. The correlations are substantiated between the burner main structural parameters for the wood waste burning. The ratio $\mathrm{D} / \mathrm{d}$ must be 2.8 , and the general height of the cone must be up to 2.2 of the of the fluidized bed height in a steady state.

\section{References}

[1] Sahu S.G., Chakraborty N., Sarkar P. Coalbiomass co-combustion: An overview. Renewable and Sustainable Energy Reviews, 2014, no. 39, pp. 575-586.

[2] Morris J.D., Daood S.S., Chilton S., Nimmo W. Mechanisms and mitigation of agglomeration during fluidized bed combustion of biomass: A review. Fuel, 2018, vol. 230, pp. 452-473.

[3] Wu K., de Martín L., Coppens M.O. Pattern formation in pulsed gas-solid fluidized beds The role of granular solid mechanics. Chemical Engineering Journal, 2017, vol. 329, pp. 4-14.

[4] Thapa R.K., Frohner A., Tondl G., Pfeifer C., Halvorse B.M. Circulating fluidized bed combustion reactor: Computational Particle Fluid Dynamic model validation and gas feed position optimization. Computers \& Chemical Engineering, 2016, vol. 92, pp. 180-188.

[5] Okasha F., Zaater G., El-Emam S., Awad M., Zeidan E. Co-combustion of biomass and gaseous fuel in a novel configuration of fluidized bed: Combustion characteristics, Fuel, 2014, vol. 133, pp. 143-152.

[6] Skopec P., Hrdlička J., Vodička M., Pilař L., Opatřil J. Combustion of Lignite Coal in a Bubbling Fluidized Bed Combustor under Oxyfuel Conditions. Energy Procedia, 2017, vol. 114, pp. 600-607.

[7] Jiang D.H., Xuguang D.H. J., Lv G., Chi Yong, Jianhua Yan. Co-combustion of tannery sludge in a commercial circulating fluidized bed boiler. Waste Management, 2015, vol. 46, pp. 227-233.

[8] Pereira C.C. Influence of particle fragmentation and non-sphericity on the determination of diffusive and kinetic fluidized bed biochar combustion data. Fuel, 2014, vol. 131, pp. 7788.

[9] Chaivatamaset P.A, Sricharoon P., Tiaa S., Bilitewskib B. Prediction of defluidization time in biomass fired fluidized bed combustion. Applied Thermal Engineering, 2013, vol. 50, pp. 722-731.

[10] Bibrzycki J., Mancini M., jSzlęka A., Weber R.A char combustion sub-model for CFDpredictions of fluidized bed combustion experiments and mathematical modeling.
Combustion and Flame, 2016, vol. 163, pp. 188201.

[11] Chyanga C.S., Duan F., Lin S.M., Tso J. A study on fluidized bed combustion characteristics of corncob in three different combustion modes. Bioresource Technology, 2012, vol. 116, pp. 184-189.

[12] Pleshanov K.A., Khlyst E.G., Maslov R.S. [Development of new power fluidized bed boilers for burning bark and wood waste]. Trudy Mezhdunarodnoi nauchno-practicheskoi conferentsii "Informatsiya inginernogo obrazovaniya" [Proceedings of the International Scientific and Practical Conference "Information for Engineering Education"]. Moscow, 2016, pp. 399-402. (In Russian).

[13] Abdulhusein A.F.Sh. [Combustion of biofuels in Iraq using fluidized bed boilers for cogeneration]. Materialy IV Mezhdunarodnoi nauchno-tekhnicheskoi conferentsii studentov, molodykh ychenykh I specialistov [International scientific and technical conference of students, young scientists and specialists]. Tombow, 2017, pp. 240-242.

[14] Ryabov G. A. Nauchnoe obosnovanie ispol'zovaniya tekhnologii szhiganiya tvyordykh topliv $v$ tsirkuliruyushchem sloe. Diss. dokt. tekh. nauk [Scientific substantiation of the use of solid fuel combustion technology in a circulating bed. Dr. of tech.]. Moscow, 2016. 291 p.

[15] Vikhryov Yu.V. Novyi parovoi kotyol energobloka moshchnost'yu $200 \mathrm{MVt}$ dlya sziganiya drevesnykh otkhodov $\mathrm{v}$ tsirkuliruyushchem sloe [New steam boiler of a 200 MW power unit for burning wood waste in a circulating fluidized bed]. Energetika $z a$ rubezhom - Energy abroad, 2016, no. 1, pp. 2527. (In Russian).

[16] Gorr D.A., Valyuzhicnich M.A., Kormil'tsyn V.I. Razrabotka rekomendatsiy po prigotovleniyu i szhiganiyu toplivnykh granul na osnove torfa $\mathrm{V}$ «kipyashchem sloe» energeticheskikh kotlov [Development of recommendations for the preparation and combustion of peat-based fuel pellets in a "fluidized bed" of power boilers]. Energosberezhenie i vodopodgotovka - Energy saving and water treatment, 2014, no. 2(88), pp. 18-21. (In Russian).

[17] Sidorov A.M., Skryabin A.A., Meleshin A.A., Usol'tsev N.V. Rekonstruktsiya kotlov KV-TS20 dlya szhiganiya nizkosortnykh topliv $\mathrm{v}$ forcirovannom sloe [Reconstruction of boilers KV-TS-20 for combustion of low-grade fuels in a forced bed]. Promyshlennaya energetika Industrial energy, 2009, no. 11, pp. 13-18. (In Russian).

[18] Sheverdyaev O.N., Gvozdyov V.M., Pakhomov A.V., Zheltova V.V. Szhiganie v kipyashchem 
sloe - perspektivnaya tekhologiya dlya nizkosortnykh topliv [Fluidized bed combustion is a promising technology for low-grade fuels]. Energosberezhenie $i$ vodopodgotovka - Energy saving and water treatment,2010, no. 6, pp. 3941. (In Russian).

[19] Karnitskiy N.B., Chizh V.A., Nerez'ko A.V., Zamara S.V. Opredelenie skorosti zanosa i prochnosti otlozheniy na ekrannykh trubakh kotla pri szhiganii lignina $\mathrm{v}$ kipyashchem sloe [Determination of the drift rate and the strength of deposits on the boiler wall tubes during the combustion of lignin in a fluidized bed]. Energetik - Energetic, 2008, no. 10, pp. 23-24. (In Russian).

[20] Karp I.N., Provalov A.Yu., P'yanykh K.E., Yudin A.S. Issledovanie dinamiki vygoraniya drevesnykh opilok i luzgi podsolnechnika $\mathrm{V}$ kipyashchem sloe [Investigation of the dynamics of burnout of sawdust and sunflower husk in a fluidized bed]. Energotekhnologii $i$ resursosberezhenie - Energy technology and resource conservation, 2010, no. 3, pp. 9-13. (In Russian).

[21] Karp I.N., Kolesnik V.V., Orlik V.N., P'yanykh K.E., Yudin A.S. Matematicheskoe modelirovanie protsesa sgoreniya drevesnoy chastitsy [Mathematical modeling of the combustion process of wood particles]. Energotekhnologii $i$ resursosberezhenie Energy technology and resource conservation, 2010, no. 5, pp. 14-20. (In Russian).

[22] Arromdee P., Kuprianov V. I. Combustion of peanut shells in a cone-shaped bubbling fluidized-bed combustor using alumina as the bed material. Applied Energy, 2012, vol. 97, pp. 470-482.

[23] Hamawand I., Silva W., Jawad A. Conical Fluidized Bed with Arc Design for Improved Performance of Gas Distributor. Studies in Engineering and Technology, 2015, vol. 2, no. 1, pp. 33-46.

[24] Ninduangdee P., Kuprianov V. I. Experimental investigation and empirical modeling of flow regimes and hydrodynamic characteristics of a cone-shaped bed using sand-biomass binary mixtures. Chemical Engineering and Processing - Process Intensification, 2018, vol. 131, pp. 111.

[25] Li F., Liu, H. Shen, X., Zeng, Q. Influence of the Air Distributor form on Flaky Particles Fluidization Characteristics in a Fluidized Bed. International Journal of Chemical Reactor Engineering, 2017, vol. 15(6), pp. 20160100.

[26] Bowers K. E, Westerman P. W. Performance of cone-shaped fluidized bed struvite crystallizers in removing phosphorus from wastewater. Transactions of the ASAE, 2005, vol. 48 (3), pp. 1227-1234.
[27] Vikhryov Yu.V. Razrabotka i osvoenie energoustanovki po szhiganiyu otkhodov $\mathrm{v}$ kipyashchem sloe [Development and mastering of a energy installation for the incineration of waste in a fluidized bed]. Energetika za rubezhom - Energy abroad, 2005, no. 5, pp. 3841. (In Russian).

[28] Basok B.I., Davidenko B.V., Novikov V.I., Goncharuk S.M. Chysel'ne modelyuvannya vykhidnogo povitryanogo potoku $\mathrm{Z}$ chastynkamy biopalyva [Numerical simulation of the outgoing air flow with biofuel particles]. Promyslova teplotekhnika - Industrial heat engineering, 2017, no. 5, pp. 84-90. (In Ukrainian).

[29] Tugov A.N., Rodionov V.I., Ugnachev V.I., Smirnov A.N., Romanov V.V., Gendel'sman M.E., Kolin I.B. Rezul'taty osvoeniya i perspektivy ispol'zovaniya tekhnologii szhiganiya otkhodov v vikhrevom kipyashchem sloe [The results of the development and prospects for the use of waste incineration technology in a vortex fluidized bed]. Elektricheskie stantsii - Power plants, 2006, no. 6, pp. 20-26. (In Russian).

[30] Mazza, G.D., Soria, J.M., Gauthier, D. et al. Environmental Friendly Fluidized Bed Combustion of Solid Fuels: A Review About Local Scale Modeling of Char Heterogeneous Combustion. Waste Biomass Valor, 2016, vol. 7, pp. 237-266.

[31] Castilla G. M., Montañés R. M., Pallarès D., and Johnsson F. Dynamic Modeling of the Reactive Side in Large-Scale Fluidized Bed Boilers. Industrial \& Engineering Chemistry Research, 2021, vol. 60 (10), pp. 3936-3956.

[32] Sivakandhan C., Murali, G. An Experimental Study of Updraft Biomass Gasifier Using Biofuels. Ecology, Environment and Conservation, 2018, vol. 24, pp. 119-125.

[33] Ismail T. M, El-Salam M. A. Parametric studies on biomass gasification process on updraft gasifier high temperature air gasification. Applied Thermal Engineering, 2017, vol. 112, pp. 14601473.

[34] Díez H. E., Gómez I. N., Pérez J. F. Mass, energy, and exergy analysis of the microgasification process in a top-lit updraft reactor: Effects of firewood type and forced primary airflow. Sustainable Energy Technologies and Assessments, 2018, vol. 29, pp. 82-91.

[35] Leva M. Fluidization. McGraw-Hill, 1959, 327 p.

[36] Davidson J.F., Clift R., Harrison D. Fluidization. Second Ed. Academic Press, Inc., 1985, 733 p.

[37] Gel'perin N. I., Aynshteyn V. G., Kvasha V. B. Osnovy tekhniki psevdozhizheniya [Fundamentals of fluidization technology], Moskva, 1967, $664 \mathrm{p}$. 
[38] Gorbis Z. R. Teploobmen i gidromekhanika dispersnykh skvoznykh potokov [Heat transfer and hydromechanics of dispersed through flows], Moskva, 1970, $423 \mathrm{p}$.

[39] Pomerantsev V. V. etc. Osnovy prakticheskoy teorii gorenia [Fundamentals of practical combustion theory], Moskva, 1986, 312 p.

\section{Information about authors.}

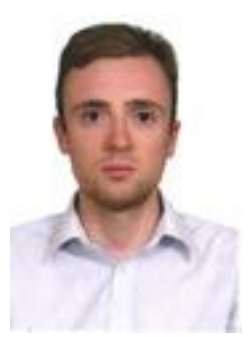

\section{Pivnenko Yurii}

$\mathrm{PhD}$, assistant of KNUCEA. Research interests: use of fluidized bed technology in power engineering, purification of process gases and ventilation emissions, lowgrade power engineering.

E-mail:

Pivnenko.Yura@gmail.com

\section{Redko Ihor}

Doctor of Technical Sciences,

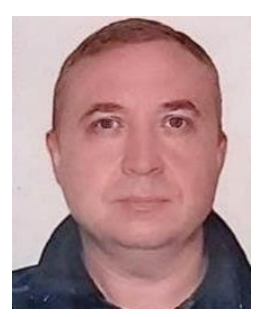

Professor of USUoRT.

Research interests: use of renewable energy sources, low-grade energy, heat and mass transfer,

thermodynamics.

E-mail:

ihor.redko1972@gmail.com

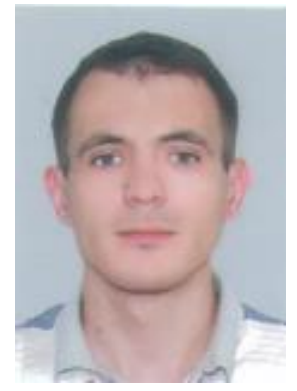

\section{Sergei Alferov}

post-graduate student of KNUCEA. Research interests: low-grade power engineering, layered solid fuel combustion, solar energy, thermal physics. E-mail: sergey.alf312@gmail.com
[40] Todes O. M., Tsitovich O. B. Apparaty s kipyashchim zernistym sloem: Gidravlicheskiye I teplovye osnovy raboty [Fluidized Bed Apparatus: Hydraulic and Thermal Basics of Operation], Leningrad, 1981, 296 p.

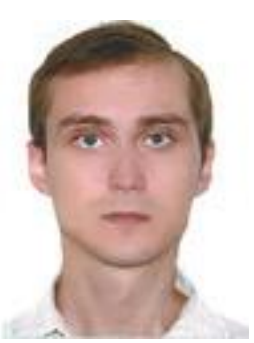

\section{Burda Yurii}

PhD, KNUCEA. Research interests: purification of ventilation emissions, rational use of boiler combustion products, alternative energy, thermodynamics.

E-mail:

burda.yurii.1991@gmail.com

\section{Cherednik Artem}

$\mathrm{PhD}$, associate professor of KNUCEA. Research interests: radiant hot water ceiling heating, decentralized ventilation for schools and civil buildings. E-mail: artemcherednicc@gmail.com 